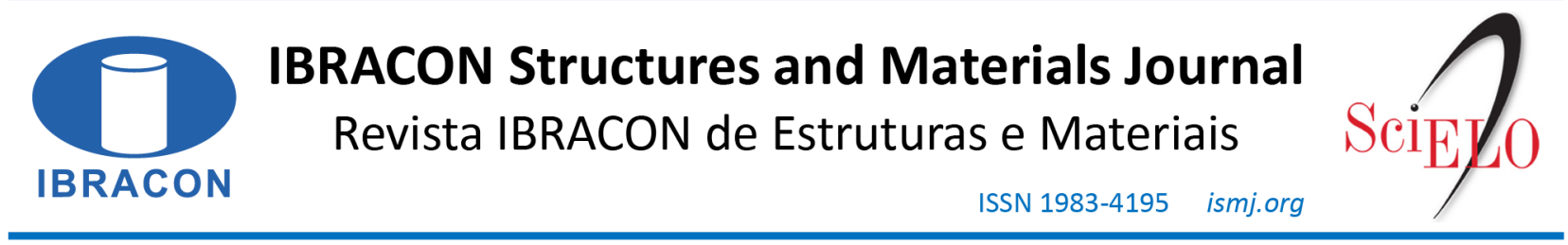

ORIGINAL ARTICLE

\title{
Seismic analysis of reinforced concrete buildings with participating masonry infills
}

\section{Análise sísmica de edifícios de concreto armado com alvenarias participantes}

\author{
Gerson Moacyr Sisniegas Alva ${ }^{a}$ (D) \\ Alessandro Onofre Rigão ${ }^{b}$ (i) \\ João Kaminski Junior ${ }^{\mathrm{c}}$ (1) \\ Marco Antônio Silva Pinheiro ${ }^{c}$
}

\author{
${ }^{a}$ Universidade Federal de Uberlândia - UFU, Faculdade de Engenharia Civil, Uberlândia, MG, Brasil \\ ${ }^{b}$ Universidade Federal de Santa Maria - UFSM, Coordenadoria Acadêmica, Cachoeira do Sul, RS, Brasil \\ 'Universidade Federal de Santa Maria - UFSM, Departamento de Estruturas e Construção Civil, Santa Maria, RS, Brasil
}

Received 18 June 2020

Accepted 22 October 2020

\begin{abstract}
In this paper, seismic analyses are performed of a reinforced concrete frame building with participating masonry walls are carried out. The spectral method of the Brazilian code - ABNT 15421:2006 - was used to obtain the lateral seismic loads. The equivalent diagonal-strut model was employed to simulate the axial stiffness of the masonry walls in the frames, according to different formulations founded in literature. The main purpose is to evaluate the differences implemented by the different formulations for the equivalent strut on the seismic response. This paper also aims at comparing results obtained when the masonry stiffness is not considered under seismic loads. The results obtained are analyzed with the purpose of providing contributions for structural engineers in the design of framed structure buildings with participating masonry walls subjected to seismic loads.
\end{abstract}

Keywords: participating masonry, infilled frames, dynamic analysis; structural analysis.

Resumo: Neste trabalho são realizadas análises sísmicas em edifício de concreto armado com sistema estrutural de pórticos preenchidos com alvenarias participantes. Para a determinação das forças sísmicas, utiliza-se o método espectral da ABNT NBR 15421:2006. Para a simulação da rigidez axial das alvenarias nos pórticos emprega-se o modelo de diagonal equivalente, segundo diversas expressões encontradas na literatura. O principal objetivo é avaliar as diferenças entre essas expressões da literatura para a diagonal equivalente na resposta sísmica. Outro objetivo é de comparar resultados ao se desconsiderar a rigidez das alvenarias sob a ação sísmica. Os resultados são comentados e fornecem contribuições a engenheiros estruturais para o projeto de estruturas aporticadas de edifícios com alvenarias participantes submetidos a ações sísmicas.

Palavras-chave: alvenarias participantes, pórticos preenchidos, análise dinâmica, análise estrutural.

How to cite: G. M. S. Alva, A. O. Rigão, J. Kaminski Junior, and M. A. S. Pinheiro, "Seismic analysis of reinforced concrete buildings with participating masonry infills," Rev. IBRACON Estrut. Mater., vol. 14, no. 3, e14315, 2021, https://doi.org/10.1590/S1983-41952021000300015

\section{INTRODUCTION}

The infill masonry walls in framed structures are always present in multi-story concrete buildings, especially for use in sealing functions. Masonry walls that have only a sealing function are not considered as participating elements in the design of the structure and, for this reason, are not included in the structural model. However, the presence of these masonry walls influences static and dynamic behavior of structural systems subjected to lateral loads (wind and seismic forces). In seismic regions, infill walls affect strength, stiffness and ductility in framed structures and may lead to harmful failure modes, as seen with shear hinges in the columns due to the short column effect. Consequently, infilled frames have been the subject of a lot of research over the last four decades. 
In Brazil, structural designs usually disregard infill masonry walls in the structural model, although their inclusion may provide important information regarding the cracking states of walls due to excessive lateral deflection of buildings - Alva et al. [1], Silva [2], Alva and Montandon [3] - and better accuracy in assessments of human comfort and wind dynamic effects in tall buildings. Noteworthy here is that in Brazil there is currently no code in force dealing with infill masonry walls with a structural function in frame buildings. In the building codes of various countries, there are several codes that deal with such masonry, including the American codes ATC FEMA 306 [4] and MSJC TMS 402-16 [5], the Canadian code CSA S304 [6] and the New Zealand code NZS 4230 [7].

In 2017, the Structural Masonry Study Commission (CE-002: 123.010) of the Brazilian Civil Construction Committee (ABNT/CB-002) was installed to update and unify the codes for structural masonry of clay blocks - ABNT NBR 15812 [8] - and concrete blocks - ABNT NBR 15961 [9]. The new code for design - ABNT NBR 16868-1 [10] was approved and published in 2020. Annex D of this code presents a proposal (informative) for the consideration of infill masonry walls as part of the bracing system, known as participating masonry. The code defines participating masonry as structural masonry built inside a frame intentionally designed and built as part of the bracing system. The code uses the Canadian code CSA S304 [6] as a basis and recommends the equivalent diagonal model for the consideration of participating masonry. It is possible that the future approval of the Brazilian code for updated and unified structural masonry will encourage the use of participating masonry in the country. This could be introduced as another option for increasing stiffness and strength under lateral loads at Ultimate and Service Limit States checks of the entire structural system.

In terms of seismic events, Rodrigues et al. [11] highlight that South America has distinct regions in terms of seismic activity. The western border has high seismic activity, due to its location on the boundary between tectonic plates, which justifies the fact that the countries located in this region have had codes for seismic design for decades. On the other hand, the eastern border is inside an internal tectonic plate, which ensures greater stability and reduced seismic activities. In Brazil, it was only in 2006 that the first code for seismic design was approved - ABNT NBR 15421 [12]. However, Rodrigues et al. [11] warn that more recent studies developed by the University of São Paulo point to the need to update seismic mapping in Brazil. The study by Nóbrega et al. [13] indicates that although seismic activity in Brazil is less frequent with low magnitudes, it should not be overlooked and highlight the fact that ABNT NBR 15421 [12] presents a seismic acceleration map, based on a worldwide study carried out in the 1990's. However, new studies have been proposed changes to this map, noting that it does not correspond well to the actual situation, with an underestimation of seismic actions in some regions. For these reasons, it is expected that the consideration of seismic actions in structural projects will be more frequent, as a consequence of the growth in research on the subject in Brazil, followed by the updating of seismic records in the country.

This paper presents numerical simulations of a multistory reinforced concrete frame building with participating masonry walls submitted to lateral seismic loads. The main objective of this paper is the quantitative comparison of results provided by several formulations proposed in the literature to obtain the axial stiffness of the equivalent diagonal-struts, which simulate the presence of the masonry under lateral loads. This paper also aims at comparing results in the case when the presence of masonry is overlooked concerning the structural behavior under seismic loads.

\section{PREVIOUS STUDIES IN LITERATURE}

In international literature, there are many publications on research involving experimental investigations based on masonry infilled frames. As key examples, emphasis is placed on studies from Mehrabi et al. [14], Durrani and Haider [15], Flanagan and Bennett [16], Al-Chaar et al. [17], Asteris et al. [18], Tasnimi and Mohebkhah [19], Liu and Manesh [20], Mansouri et al. [21], Basha and Kaushik [22] and Morandi et al. [23]. Experimental investigations cover both concrete and steel frames, which are strongly motivated toward behavior experienced under seismic loads. The analysis of the failure modes, the influence of the presence of openings on the walls, the simulation of old structures designed for gravity loads only, the absence or deficiency of the seismic detailing of the concrete structure and the study of the damage limitation (seismic performance levels) due to the relative displacements between stories are the object of study in most experimental investigations.

Numerical modelling with the aid of the Finite Element Method (FEM) is an effective tool for studying the behavior of masonry infilled frames, mainly due to the costs and operational difficulties for carrying out experimental tests. Among the various studies related to the use of the FEM for numerical analysis of infilled frames over the last two decades, one finds Doudoumis [24], Mondal and Jain [25], Asteris [26], Gosh and Amde [27], Mohyeddin et al. [28], Stavridis and Shing [29], Baloevic et al. [30] and Mohammadi and Motovali Emami [31]. In most of these studies, the numerical simulations consider the material nonlinearity, the failure criterion/plastification of the materials and aim at generating the analysis of the behavior of infilled frames in terms of stiffness, strength and failure modes. The influence of the presence of openings is also an object of study, also included in linear analysis [25]. 
Simplified models that simulate the infill walls by equivalent diagonal-struts are quite attractive in the analysis of infilled frames subjected to lateral loads, particularly in structural design, due to their simplicity. The models with a single diagonal-strut are very well established and provide satisfactory results, as long as a suitable formulation is chosen to obtain the axial stiffness of the equivalent diagonal-strut (or for the equivalent diagonal width, according to Section 3). The limitations of single diagonal models and the application of models with multiple-strut models are discussed in Crisafulli et al. [32], El-Dakhakhni et al. [33], Asteris et al. [34], Fiore et al. [35], Uva et al. [36] and Sattar and Liel [37].

Infilled masonry walls have great influence on obtaining the fundamental period of vibration of the structure, an essential parameter in the design of structures subjected to seismic loads. According to Asteris et al. [38], although there are several analytical formulations in the literature and in design codes for estimating the fundamental period of the structure, most of these do not take into account the presence of masonry nor the presence of openings on the walls, factors that evidently influence the structure stiffness. In addition, such expressions, by not considering the presence of filling masonry, are unable to capture the effects of irregularities in the arrangement of masonry along the height or across the spans on the fundamental period of the building. Research conducted by Amanat and Hoque [39] points out that conventional modal analysis by FEM, which does not include the presence of infill masonry walls, generally provides fundamental periods longer than those measured in buildings. For this reason, design codes impose an upper limit on the fundamental period obtained from modal analysis. The effect of infill masonry walls on the fundamental period of vibration of buildings subjected to seismic loads can be found in Asteris et al. [38], Amanat and Hoque [39], Kose [40], Ricci et al. [41], Perrone et al. [42] and Asteris et al. [43].

In Brazil, research on infill masonry walls in frame structural systems began two decades ago. From such research, the following studies are noted: Alvarenga [44], Santos [45], Tanaka [46], Madia [47], Silva [2], Sousa [48], Pitanga [49], Montandon [50], Medeiros [51], Grandi [52]. The studies conducted by Alvarenga [44] and Grandi [52] brought pioneering national contributions on the experimental behavior of masonry infilled steel frames. The cited studies were generally dedicated to numerical modeling by FEM [2], [45], [46], [48]-[51], using equivalent strut modelling [2], [44], [45], [47], [48], [50]-[52] and analysis of the influence felt from the presence of openings [2], [46]. In the analysis of buildings carried out in the referred studies, only wind loading was considered. There is a lack of national investigations involving seismic analysis in buildings with participating masonry walls.

In the investigations by Silva [2] and Montandon [50], several numerical simulations of infilled frames were carried out to analyze the Limit States of cracking (in service) of the masonry infills caused by the excessive lateral deflections of the structure subjected to wind loading. In these two studies, the results provided by different expressions proposed in the literature were also compared to obtain the equivalent diagonal width, concluding that the Durrani and Luo [53] expression is the one that provides results closest to those provided with $2 \mathrm{D}$ modelling including the contact problem between masonry-frame, with the aid of the ANSYS program.

\section{MODELLING OF MASONRY INFILLED FRAMES}

The lateral loads (seismic and wind forces) acting on the structural systems of masonry tend to produce the deformed shape illustrated in Figure 1a, with separation between the frame structural members and the infill masonry walls in the tensile corners and the formation of a compressive stress field across the diagonal of the wall.

The simplest and most used model in structural design for considering the interaction between frame and masonry under lateral loads is the equivalent diagonal-strut model, which is covered by several codes. In this model, the wall is represented by a pinned diagonal member, whose section is defined by the thickness of the wall and the so-called equivalent diagonal-strut width (a), as shown in Figure $1 \mathrm{~b}$.

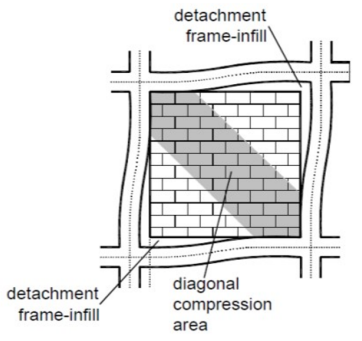

a)

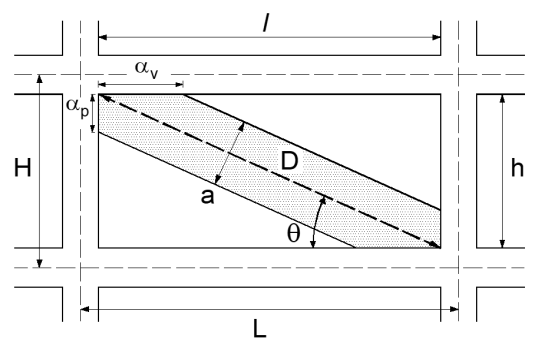

b)

Figure 1. a) Effects of lateral loads on masonry infilled frames - Asteris et al. [18]. b) Dimensions used for calculating the equivalent diagonal-strut width - Silva [2] 
There are several expressions proposed in specialized literature for calculating the equivalent diagonal width, such as those contained in Table 1. Other expressions, in addition to these, are presented in Table 1 and can be found in Asteris et al. [34] and in Morandi et al. [23]. All parameters in Table 1 are explained in Montandon [50].

The expression proposed by Mainstone [54] is the best known in the literature and is used, for example, in codes such as ATC FEMA [4]. The Canadian standard CSA S304 [6] adopts the expression as proposed by Hendry [55], taking as an upper limit the equivalent width value proposed by Paulay and Priestley [58]. The Brazilian code ABNT NBR 16868-1 [10] proposes the same expression as the Canadian standard.

The various expressions found in the literature lead to quite different results. In many cases, the ratio between the largest and the smallest width provided by the expressions can reach differences of up to three times one from another. The expression presented in Mainstone [54] is known to provide the lowest values of equivalent diagonal width. The results provided by several expressions proposed in the literature for the equivalent diagonal width were recently published in Alva and Montandon [3] for different geometric characteristics of frames and masonry.

Table 1. Analytical equations for calculation of the equivalent strut width

\begin{tabular}{|c|c|}
\hline Authors & Expression \\
\hline Mainstone [54] & $a=0.175\left(\lambda_{H}\right)^{-0,4} D$ \\
\hline Hendry [55] & $\alpha_{v}=\frac{\pi}{\lambda_{p}} \leq l \quad \alpha_{p}=\frac{\pi}{2 \lambda_{p}} \leq h$ \\
\hline Liauw and Kwan [56] & $a=\frac{0.95 \operatorname{sen}(2 \theta)}{2 \sqrt{\lambda_{H}}} D$ \\
\hline \multirow{2}{*}{ Decanini and Fantin [57]: cracked } & $\lambda_{H} \leq 7.85 \quad a=\left(0.010+\frac{0.707}{\lambda_{H}}\right) D$ \\
\hline & $\lambda_{H}>7.85 \quad a=\left(0.040+\frac{0.470}{\lambda_{H}}\right) D$ \\
\hline Paulay and Priestley [58] & $a=\frac{D}{4}$ \\
\hline \multirow{3}{*}{ Durrani and Luo [53] } & $a=\gamma \operatorname{sen}(2 \theta) D$ \\
\hline & $\gamma=0.32 \sqrt{\operatorname{sen}(2 \theta)}\left(\frac{H^{4} E t}{m E_{p} I_{p} h}\right)^{-0.1}$ \\
\hline & $m=6\left(\frac{1+6 E_{V} I_{V} H}{\pi E_{P} I_{P} L}\right)$ \\
\hline Chrysostomou and Asteris [59] & $a=0.27\left(\lambda_{H}\right)^{-0.4} D$ \\
\hline
\end{tabular}

The modeling of masonry infilled frames can also be performed using FEM with 2D or 3D finite elements, considering the separation and sliding between the two surfaces (masonry-frame) and, when necessary, the material nonlinearity. Research by Asteris et al. [60] presents a complete overview (state of the art) on the different strategies for this type of modeling, with comments on the advantages and disadvantages of each.

In turn, as demonstrated in Doudoumis [24] and Asteris et al. [60], the modeling via FEM with finite elements for plane stress and material linear analysis can be useful in different situations, such as the verification of more simplified models, also serving to measure the expressions proposed for determining the equivalent diagonal width. This type of modeling was used more recently in investigations by Silva [2], Alva et al. [1], Montandon [50], Alva and Montandon [3], and will be touched upon in Section 4.2.3.

\section{NUMERICAL SIMULATIONS: MULTISTORY BUILDING}

In order to achieve the main objectives of this paper, numerical simulations were carried out on a multistory reinforced concrete building with participating masonry walls. The case of the absence of masonry was also included 
for comparative purposes. All information regarding the building can be found in Section 4.1, including that necessary for the determination of seismic forces.

As previously mentioned, the central focus of the analysis is the comparison of results ascertained through the use of different expressions proposed in the literature for the equivalent diagonal width in frame structural models.

The modal analysis was performed with different hierarchical models (Section 4.2), for the purpose of comparison and validation of results of the model used in the determination of the seismic loads.

For the seismic analysis, the spectral method of ABNT NBR 15421 [12] was used, the data from this method, used for determining the design response spectrum, can be found in Section 4.3. The spectral method was chosen due to it demonstrating sufficient accuracy for structural design applications, as well as being simpler than method based on response history analysis.

\subsection{Investigated Building}

This numerical example consists of a 12-story (hypothetical) commercial building of reinforced concrete (including a roof) with a structural system that consists of frames in both orthogonal directions. The structural plan view is shown in Figure 2. The building was investigated by Alva et al. [61], who assumed seismic zone 0 (city of São Carlos-SP), thus neglecting seismic actions. This figure also indicates the frame chosen in the analysis of this paper.

A floor to floor height of $3.0 \mathrm{~m}$ is specified. Beams and columns were designed according to ABNT NBR 6118 [62] and the participating masonry walls, were in accordance with code ABNT NBR 16868-1 [10]. For this paper, the building under consideration is located in the city of Rio Branco-AC, supported on soil that exhibits an average number of blows from SPT test equal to 25 for the $30 \mathrm{~m}$ below the ground surface. In terms of reinforcement detailing, a concrete frame designed with standard detailing will be employed, which corresponds to the criteria established in ABNT NBR 6118 [62]. In turn, the gravity loads are the same as those adopted by Alva et al. [61]. In order to obtain gravity loads, the following values were assumed: $25 \mathrm{kN} / \mathrm{m}^{3}$ for the self-weight of reinforced concrete, walls in all beams $\left(2.5 \mathrm{kN} / \mathrm{m}^{2}\right.$ of masonry wall $)$ and $2.0 \mathrm{kN} / \mathrm{m}^{2}$ for the live load.

Flexural stiffness reductions were applied for beams and columns, in order to take into account material nonlinearity (in an approximate approach) according to ABNT NBR 6118 [62].

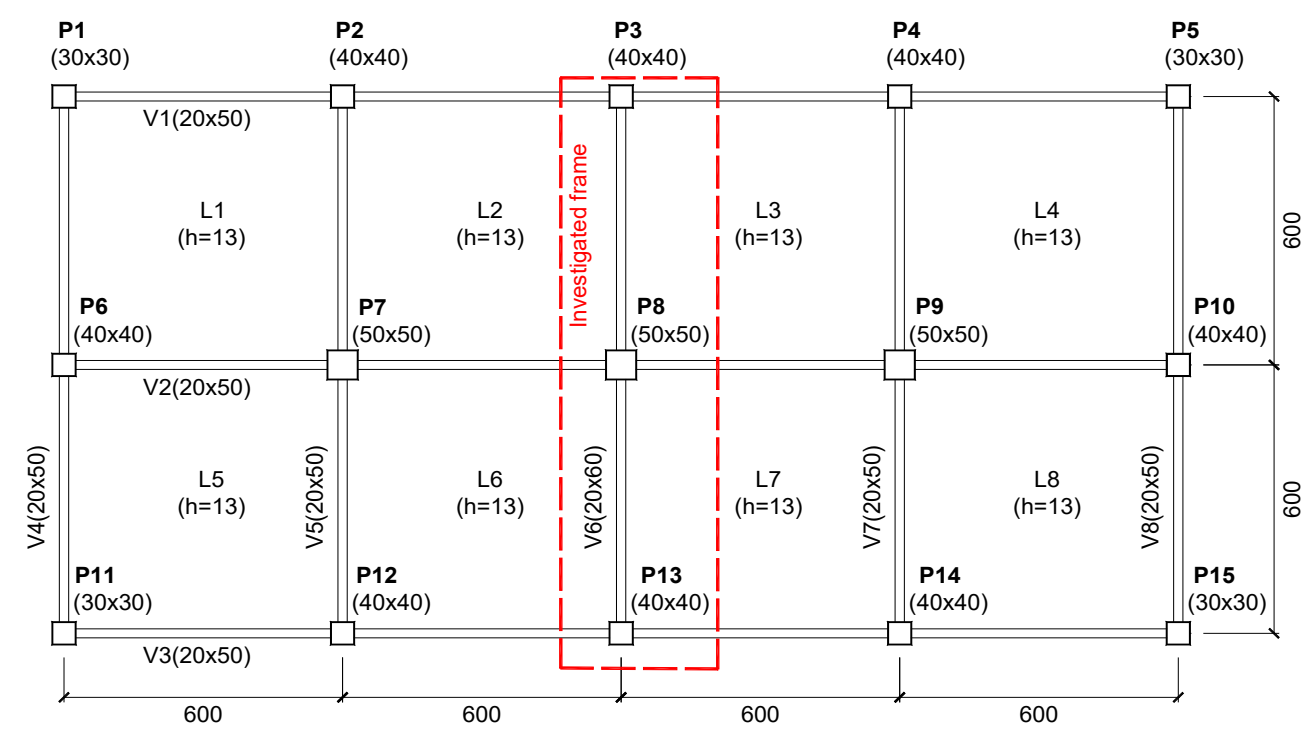

Figure 2. Structural plan view of the analyzed building

For pre-assessment purposes, seismic loads were calculated using the Equivalent Lateral Force Method, which were applied to the frame without the presence of participating masonry walls. The design of beams and columns in this situation indicated that the sections and the concrete strength of these elements could be kept the same as the building investigated in Alva et al. [61].

Thus, the specification of the materials is: 
Reinforced concrete structure:

- Compressive strength of concrete (beams and columns): C40 for the first two stories and C25 for the other stories;

- Modulus of elasticity of concrete (beams and columns): $E_{c}=35 \mathrm{GPa}$ for the first two stories and $E_{c}=28 \mathrm{GPa}$ for the other stories;

- Longitudinal steel reinforcement of beams and columns: CA-50.

As for the criterion of durability, environmental aggressiveness class II was assumed, with concrete cover of beams and columns equal to $3.0 \mathrm{~cm}$.

Participating masonry:

- Hollow clay blocks with solid wall

- Participating masonry thickness (without covering): $t=19 \mathrm{~cm}$

- Thickness of longitudinal block walls: $2.2 \mathrm{~cm}$

- Characteristic compressive strength of block unit: $f_{b k}=10.0 \mathrm{MPa}$

- Average compressive strength of mortar: $f_{a}=8.0 \mathrm{MPa}$

- Characteristic compressive strength of prism: $f_{p k}=6.0 \mathrm{MPa}$

- Height of participating masonry walls: $h=240 \mathrm{~cm}$

- Length of participating masonry walls: $l=555 \mathrm{~cm}$

- Modulus of elasticity of participating masonry: $E_{a}=3.6 \mathrm{GPa}$

\subsection{Modal Analysis: applied structural models}

The modal analysis was carried out using three different hierarchical models: one simple (shear building models, according to Section 4.2.1), a model with intermediary hierarchical order (plane frame model with equivalent diagonals, according to Section 4.2.2) and a higher hierarchical model (according to Section 4.2.3 with 2D finite elements) useful as a reference and for the validation of the simplest models.

The use of the three different hierarchical models in modal analysis is also useful for comparing results in the simulation of the first vibration modes of the structure - these are usually the most important in seismic analysis. Noteworthy here are the comparisons made on the fundamental period of vibration provided by the different models, since this parameter is of great importance in determining seismic forces with the Equivalent Lateral Force Method, present in several design codes.

The modal analysis of the models presented in Section 4.2.1 were performed using the MATHCAD program. The models presented in 4.2.2 and 4.2.3 were performed using the ANSYS (R18) program.

\subsubsection{Shear Building Models}

Shear building models (S.B.) are widely used in seismic analysis of multistory buildings and may provide good estimates of seismic behavior in buildings with rectangular and symmetric plans when compared to more refined models (such as 3D frames or FEM models). In these models, the masses are lumped at the level of each floor and the lateral stiffness of each floor is obtained from the equivalent single-degree-of-freedom oscillator.

The traditional shear building models assume the hypothesis that beams/slabs are non-deformable (have infinite axial and flexural stiffnesses) and columns are axially inextensible. In this case, each story has a degree of freedom only in the horizontal direction. The lateral stiffness of the story is obtained by the sum:

$k_{P}=\sum_{i=1}^{n c o l} 12 \frac{E I_{i}}{h^{3}}$

where

$I_{i}$ is the second moment of area (inertia) of column i of the story;

$E$ is the longitudinal modulus of elasticity of the columns;

$h$ is the distance between consecutive stories;

$n_{c o l}$ is the number of columns per story. 
However, the calculation of the lateral stiffness of the story considering the flexibility of beams and slabs allows for a more accurate assessment of the same and, consequently, of the seismic acting forces. The study by Caterino et al. [63] addresses some methods proposed in the literature to estimate the lateral stiffness of the stories and which consider the stiffness of beams and columns. In turn, the authors propose that lateral stiffness be calculated similarly to that mentioned in Equation 1:

$k_{p}=\sum_{i=1}^{n c o l} \alpha_{i} 12 \frac{E I_{i}}{h^{3}}$

where $\alpha_{i}$ is a dimensionless coefficient which varies between 0.25 and 1 and depends on the degree of rotational restraint imposed by the beams on the adjacent column. The $\alpha_{i}$ coefficient is calculated using expressions that depend on the flexural stiffness of beams, columns and the estimated position of the points of contraflexure (zero bending moment), these are found in Caterino et al. [63]. The method proposed by the authors provided good results when compared to those provided by simulations of entire buildings modeled in a commercial program that uses FEM.

The presence of infill masonry walls increases the lateral stiffness of the stories. Their contribution to the lateral stiffness of the story can be obtained from the axial stiffness of the equivalent diagonal:

$k_{a}=\sum_{i=1}^{n p a r} \frac{E_{a} a t}{L} \cos \theta$

where

$E_{a}$ is the longitudinal modulus of elasticity of masonry;

$a$ is the equivalent diagonal width, which depends on the adopted expression (see Table 1);

$t$ is the wall thickness;

${ }_{L}$ is the equivalent diagonal length in the structural model;

$\theta$ is the equivalent diagonal angle in relation to the horizontal;

$n_{p a r}$ is the number of walls per story.

Similar to that performed by Gaetani d'Aragona et al. [64], the lateral stiffness of the story can be obtained by the sum of the contributions of the frame members (beam and column) and the masonry infill walls:

$k=k_{p}+k_{a}$

In this paper, the lateral stiffness of the story was obtained from the application of a unit lateral displacement in the single-story frame, as shown in Figure 3, with the axial inextensible simulation of beam and columns.

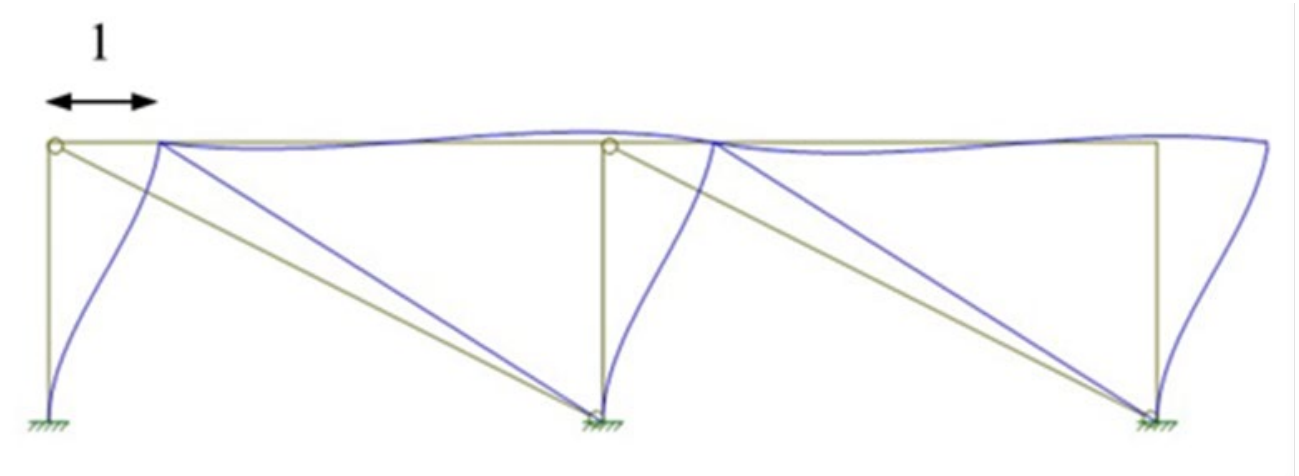

Figure 3. Lateral stiffness of each story due to unit displacement for shear building models 
The participating masonry walls are simulated by the pinned diagonal members (equivalent diagonals). On the subject of the estimation of the moment of inertia to the bending of the beams, the contribution of slabs (effective width) - as recommended by Saatcioglu and Humar [65] - as well as the eccentricity of the beam axis in relation to the median plane of the slab, as recommended by Araújo [66] have all been considered. The effective width of the slabs was obtained from the criteria of ABNT NBR 6118 [62].

The values of the equivalent diagonal width according to the expressions in Table 1 are shown in Table 2, which also shows the values of the lateral stiffness of each story with the described procedure. The lateral stiffness values of the stories were remarkably close to those calculated using Equation 4, with maximum differences of about 5\%.

Table 2. Values of the equivalent strut width and lateral stiffness (S.B. models)

\begin{tabular}{|c|c|c|c|c|}
\hline \multirow{2}{*}{$\begin{array}{c}\text { Authors } \\
\text { (EQUIVALENT STRUT WIDTH) }\end{array}$} & \multirow{2}{*}{\multicolumn{2}{|c|}{$\begin{array}{l}\text { Equivalent strut width } \\
\qquad(\mathrm{cm})\end{array}$}} & \multirow{2}{*}{\multicolumn{2}{|c|}{$\begin{array}{c}\text { Lateral stiffness (S.B.) } \\
(\mathbf{N} / \mathbf{m})\end{array}$}} \\
\hline & & & & \\
\hline & Stories & Stories & Stories & Stories \\
\hline & $1-2$ & 3-12 & $1-2$ & 3-12 \\
\hline Without infill walls & - & - & $0.9506 \times 10^{8}$ & $0.7610 \times 10^{8}$ \\
\hline CSA S304 [6] & 151.17 & 151.17 & $2.184 \times 10^{8}$ & $1.994 \times 10^{8}$ \\
\hline Mainstone [54] & 78.25 & 76.52 & $1.589 \times 10^{8}$ & $1.385 \times 10^{8}$ \\
\hline Durrani and Luo [53] & 101.52 & 99.28 & $1.779 \times 10^{8}$ & $1.571 \times 10^{8}$ \\
\hline Liauw and Kwan [56] & 143.50 & 139.56 & $2.121 \times 10^{8}$ & $1.889 \times 10^{8}$ \\
\hline Decanini and Fantin [57] & 207.06 & 196.16 & $2.640 \times 10^{8}$ & $2.361 \times 10^{8}$ \\
\hline Paulay and Priestley [58] & 151.17 & 151.17 & $2.184 \times 10^{8}$ & $1.994 \times 10^{8}$ \\
\hline Chrysostomou and Asteris [59] & 120.73 & 118.06 & $1.936 \times 10^{8}$ & $1.724 \times 10^{8}$ \\
\hline
\end{tabular}

\subsubsection{Plane Frame Models}

For the modeling of the chosen plane frame (see Figure 2), the contribution of slabs (effective width) and the effect of the eccentricity of the beam axis in relation to the median plane of the slab were considered concerning the calculation of the second moment of area (inertia) of beams, in line with the concepts of Section 4.2.1.

Regarding the finite elements of the ANSYS program, the BEAM3 element was used for beams and columns, which consists of a 2D plane frame member with three degrees of freedom per node. For the simulation of the equivalent diagonals, the LINK10 element was used, which consists of a truss member with the possibility of activating only uniaxial tension or compression. For the problem at issue, only axial compression was activated. In this case, for the correct modeling of the masonry participation according to the different vibration modes, two LINK10 elements were defined per wall. Thus, the plane frame model with participating masonry presented a configuration of the diagonals in "X".

\subsubsection{FEM-PS/Contact Models}

For a more refined modeling, numerical simulations with two-dimensional finite elements were performed, considering a plane stress (FEM-PS), including the contact problem between participating masonry and concrete frame. The numerical modeling described in this Section is demonstrated with more details in Silva [2], Alva et al. [1], Montandon [50] and Alva and Montandon [3].

PLANE182 element from the ANSYS program was used to model both concrete and masonry structures. This finite element is applicable in the case of plane stresses and has four nodes. Each node has two degrees of freedom, which are the translations in the $\mathrm{X}$ and $\mathrm{Y}$ directions. These directions form the $\mathrm{XY}$ plane along which the infilled frame is located. Regarding discretization, finite elements of dimensions $5 \mathrm{~cm}$ x $5 \mathrm{~cm}$ were defined, both for the reinforced concrete frame and for the masonry wall. The adopted discretization was based on a mesh refinement study and by Silva [2] investigations.

The CONTA172/TARGE169 elements were used for the contact pair, allowing for the simulation of sliding and separation between the surfaces of the reinforced concrete frame and the masonry wall. In the ANSYS program, the normal contact stiffness factor FKN was calibrated in order to obtain the lowest possible penetration between surfaces, but with the guarantee of numerical convergence. 
Other parameters defined in the contact problem are the friction coefficient $(\mu)$ between the masonry-frame surfaces, the maximum shear strength stress between the surfaces $\left(f_{v}, \max \right)$ and the cohesion $\left(\tau_{0}\right)$. The following values were adopted: $\mu=0.5 ; \tau_{0}=0.35 \mathrm{MPa} \mathrm{e} \mathrm{v}_{\mathrm{v}}, \max =0.365 \mathrm{MPa}$. These values were estimated based on current Brazilian structural masonry codes, assuming that the maximum possible stress at the wall-frame interface is the masonry shear strength.

Figure 4a illustrates one of the models investigated by Alva et al. [1] for a single- story infilled frame, with details of the discretization used, the deformed shape and the field of compressive principal strains. Figure $4 \mathrm{~b}$ illustrates the model used in this paper for the 12-story frame. In order to simulate slab contribution, the modulus of elasticity of the beam was increased proportionally to the gain of second moment of area (inertia) obtained considering the effective widths and the eccentricity of the beam axis in relation to the slab average plane.
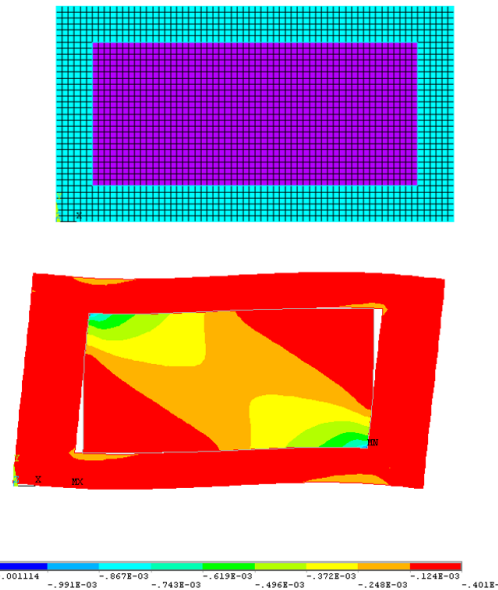

a) One-story one-bay model: Alva et al. [1]

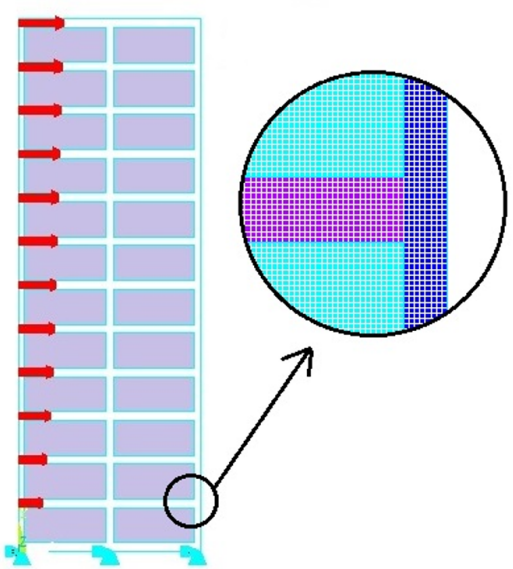

b) Model for 12 stories (used)

Figure 4. Examples of FEM-PS/Contact model

\subsubsection{Summary of applied structural models and nomenclature}

Figure 5 shows the scheme for the three structural models used in the modal analysis of this paper. The nomenclature of the shear building models and the plane frame models follow the expression used to determine the equivalent diagonal width.

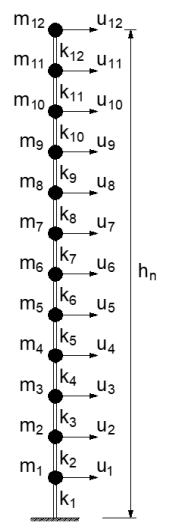

a) Shear Building

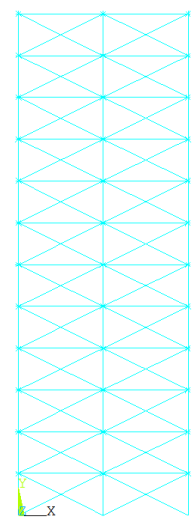

b) Plane Frame

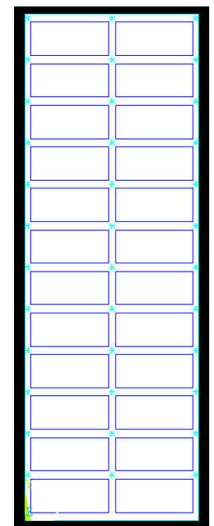

c) FEM-PS/Contact model

Figure 5. Structural models used in the modal analysis 


\subsection{Seismic analysis using the spectral method: ABNT NBR 15421 [12]}

The building is located in seismic zone 3 (Rio Branco-AC), for which the normalized horizontal (seismic) acceleration for soils class B (rock) is $0.10 \mathrm{~g}$, where $\mathrm{g}$ is the gravitational acceleration.

The design response spectrum in ABNT NBR 15421 [12] for horizontal accelerations, which assumes a damping ratio equal to $5 \%$, is defined for three ranges of periods (in s) by:

$S_{a}(T)=a_{g s 0}\left(18.75 T \frac{C_{a}}{C_{v}}+1.0\right)$ for $0 \leq T \leq 0.08 \frac{C_{v}}{C_{a}}$

$S_{a}(T)=2.5 a_{g s 0}$ for $0.08 \frac{C_{v}}{C_{a}} \leq T \leq 0.4 \frac{C_{v}}{C_{a}}$

$S_{a}(T)=\frac{a_{g s l}}{T}$ for $T \geq 0.4 \frac{C_{v}}{C_{a}}$

where

$T$ is the natural period (in seconds) for the vibration mode considered;

$a_{g s 0}$ and $a_{g s l}$ are the spectral accelerations for the $0.0 \mathrm{~s}$ and $1.0 \mathrm{~s}$ periods, respectively, with prior consideration of the soil seismic amplification effect:

$$
a_{g s 0}=C_{a} a_{g}
$$

$a_{g s l}=C_{v} a_{g}$

$C_{v}$ and $C_{a}$ are the soil seismic amplification factors, for the $0.0 \mathrm{~s}$ and $1.0 \mathrm{~s}$ periods, respectively (Table 3 from ABNT NBR 15421 [12]);

$a_{g}$ is the characteristic horizontal (seismic) acceleration.

Based on the data of the location and soil characteristics, the following values of the necessary parameters for the construction of the design spectrum were obtained, which is shown in Figure 6:

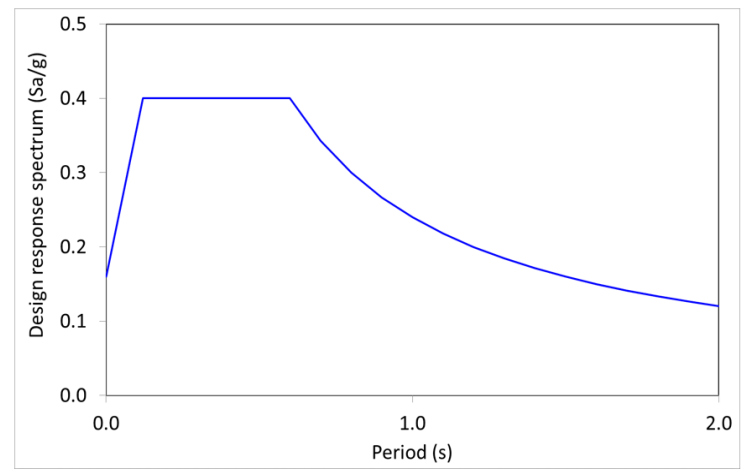

$$
\left.a_{g}=0.10 g \quad \text { (Seismic zone: } 3\right)
$$$$
C_{a}=1.6 \text { and } C_{v}=2.4
$$

(Site class: D)

Figure 6. Design response spectrum for the analyzed building: ABNT NBR 15421 [12]

Based on the nature of the building occupation and the seismic-resistant detailing chosen for the concrete structural system (frames), the coefficients applied to the modal responses (forces and displacements) in the seismic analysis are reached by the spectral method:

Importance factor $I=1.0$ (occupancy category I) 
Response-modification coefficient: $R=3.0$

Displacement amplification coefficient: $C_{d}=2.5$ (concrete frame with usual detailing)

Modal responses in terms of forces, moments and support reactions must be multiplied by $\mathrm{I} / \mathrm{R}$. In turn, the modal responses in terms of absolute and relative displacements must be multiplied by the $C_{d} / R$ factor.

\section{ANALYSIS OF THE RESULTS AND DISCUSSION}

\subsection{Modal analysis}

Figure 7 illustrates the configuration of the first three vibration modes according to the structural models mentioned in Section 4.2.

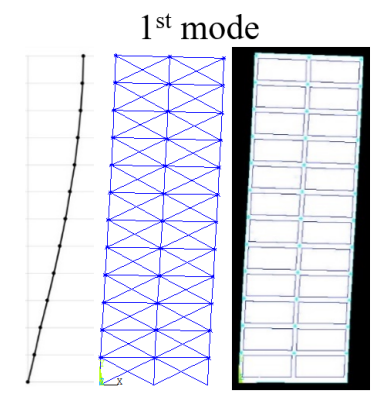

S.B. P.F. FEM-PS

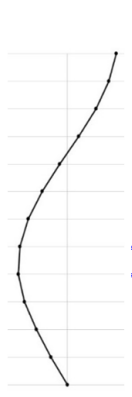

S.B.

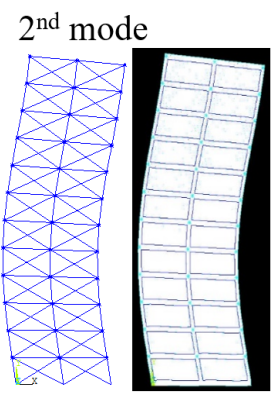

P.F. FEM-PS

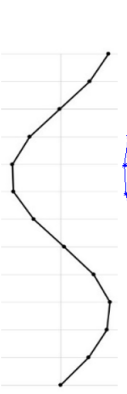

S.B.

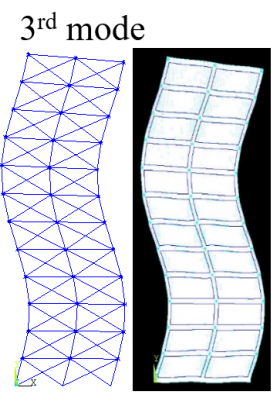

P.F. FEM-PS

Figure 7. First three mode shapes of vibration according to the applied structural models

Emphasis is here placed on the fact that the first modes contribute more significantly to the seismic response of buildings [67]. In many practical cases, consideration of the first three modes only is sufficient for most short to medium-rise buildings. For high-rise buildings, it may be necessary to consider more than three modes [65]. Table 3 shows the values of the respective natural frequencies for shear building and plane frame models. FEM-PS/Contact model led to following values for natural frequencies: $1.129 \mathrm{~Hz}\left(1^{\text {st }}\right.$ mode $), 3.633 \mathrm{~Hz}\left(2^{\text {nd }}\right.$ mode $)$ and $6.964 \mathrm{~Hz}$ $\left(3^{\text {rd }}\right.$ mode). Noteworthy here is that the first three already capture more than $94 \%$ of the total mass, for all simulated models (with and without masonry).

Table 3. Natural frequencies $(\mathrm{Hz})$ : models without and with masonry walls

\begin{tabular}{|c|c|c|c|c|c|c|}
\hline \multirow{2}{*}{$\begin{array}{c}\text { Authors } \\
\text { (EQUIVALENT STRUT WIDTH) }\end{array}$} & \multicolumn{3}{|c|}{ Shear Building } & \multicolumn{3}{|c|}{ Plane Frame } \\
\hline & $1^{\text {st }}$ mode & $2^{\text {nd }}$ mode & $3^{\text {rd }}$ mode & $1^{\text {st }}$ mode & $2^{\text {nd }}$ mode & $3^{\text {rd }}$ mode \\
\hline Without infill walls & 0.745 & 2.214 & 3.630 & 0.580 & 1.762 & 3.042 \\
\hline CSA S304 [6] & 1.183 & 3.525 & 5.728 & 1.138 & 3.600 & 6.832 \\
\hline Mainstone [54] & 0.993 & 2.956 & 4.855 & 0.960 & 2.958 & 5.938 \\
\hline Durrani and Luo [53] & 1.052 & 3.138 & 5.164 & 1.026 & 3.185 & 5.892 \\
\hline Liauw and Kwan [56] & 1.156 & 3.442 & 5.657 & 1.117 & 3.521 & 6.645 \\
\hline Decanini and Fantin [57] & 1.292 & 3.846 & 6.322 & 1.212 & 3.910 & 7.536 \\
\hline Paulay and Priestley [58] & 1.183 & 3.525 & 5.728 & 1.138 & 3.600 & 6.832 \\
\hline Chrysostomou and Asteris [59] & 1.104 & 3.289 & 5.405 & 1.072 & 3.350 & 6.258 \\
\hline
\end{tabular}

It is evident that the presence of the participating masonry walls increases the frequency of the vibration modes. For the first mode, this increase was between 33.3\% (Mainstone) and 73.4\% (Decanini and Fantin) for the shear building models, and it was between 65.5\% (Mainstone) and 108.9\% (Decanini and Fantin) for the plane frame models.

Regarding the models with participating masonry, the frequency of the first mode obtained with the FEMPS/Contact model - taken as a reference - was $1.129 \mathrm{~Hz}$. In the shear building models, the frequencies of the first mode 
were between $0.993 \mathrm{~Hz}$ (Mainstone) and $1.292 \mathrm{~Hz}$ (Decanini and Fantin), thus observing maximum differences of $13.7 \%$ regarding the reference model. Likewise, in the plane frame models, a maximum difference of $15.0 \%$ was observed concerning the reference model, with the frequencies of the first mode ranging between $0.960 \mathrm{~Hz}$ (Mainstone) and $1.212 \mathrm{~Hz}$ (Decanini and Fantin). Noted here was that, for the same expression used in the equivalent diagonal width, the shear building models provided results remarkably close to the plane frame models.

Based on the results from Table 3, one notes that the expressions of Liauw and Kwan [56] and CSA S304 [6] used, respectively, in the shear building and plane frame models, are those that came closest to the frequency of the first vibration mode of the reference model, with maximum differences around $2 \%$.

From the values of the cumulative modal effective mass fraction, it becomes evident that the first three vibration modes already capture more than $94 \%$ of the total mass for all models approached - shear building and plane frames (with and without masonry) - including for FEM-PS/Contact model.

Table 4 contains the values of the fundamental periods provided by each structural model. Worthy of mention here is that the increase in stiffness promoted by the participating masonry causes a significant decrease in the fundamental period of the structure when compared to the model without masonry. This decrease was between $25.4 \%$ and $42.3 \%$ by analyzing the shear building models. When analyzing the plane frame models, this decrease was between $39.6 \%$ and $52.1 \%$.

Table 4. Fundamental periods: models without and with masonry walls

\begin{tabular}{ccc}
\hline Authors & Shear Building & Plane Frame \\
\hline (EQUIVALENT STRUT WIDTH) & T (s) & T (s) \\
\hline Without infill walls & 1.342 & 1.724 \\
\hline CSA S304 [6] & 0.845 & 0.879 \\
\hline Mainstone [54] & 1.001 & 1.042 \\
\hline Durrani and Luo [53] & 0.951 & 0.975 \\
\hline Liauw and Kwan [56] & 0.865 & 0.895 \\
\hline Decanini and Fantin [57] & 0.774 & 0.825 \\
\hline Paulay and Priestley [58] & 0.845 & 0.879 \\
\hline Chrysostomou and Asteris [59] & 0.906 & 0.933 \\
\hline
\end{tabular}

Comparing only the models with participating masonry, the expression proposed by Mainstone [54] provides the largest fundamental period, which expresses maximum differences with the other expressions of around $23 \%$ for the shear building models and $26 \%$ for the plane frame models.

The FEM-PS/Contact model (reference) presented a fundamental period equal to 0.886s. In the shear building models, the fundamental periods were between $0.774 \mathrm{~s}$ (Decanini and Fantin) and 1.001s (Mainstone); in this case, the maximum difference is $13.7 \%$ in relation to the reference model. In the plane frame models, the fundamental periods were between $0.825 \mathrm{~s}$ (Decanini and Fantin) and 1.042s (Mainstone), thus observing a maximum difference of $15.0 \%$ regarding the reference model.

ABNT 15421 [12] presents the following expression for the approximate calculation of the fundamental period of the structure:

$T_{a}=C_{T} h_{n}{ }^{x}$

where

$C_{T}=0.0466, x=0.9$ for the case in question (seismic forces are fully resisted by concrete frames) and $h_{n}$ is the height of the building in meters.

The approximate expression of ABNT 15421 [12] provided a fundamental period $T_{a}=1.172 \mathrm{~s}$. Moreover, according to the same code, the fundamental period based on modal analysis should not exceed the value of $C_{u p} T_{a}$, with $C_{u p}=1.6$ for the case at hand (Seismic Zone 3). Thus, there is an upper limit of $C_{u p} T_{a}=1.876 \mathrm{~s}$.

The approximate period of ABNT NBR 15421 [12] was longer than those provided by modal analysis for all models with participating masonry walls. Actually, Equation 10 does not take into account the distribution of the infill walls nor geometrical-mechanical properties that these hold. Compared to the shear building and plane frame models, this 
increase was between $12.4 \%$ and $51.4 \%$. Regarding the modal analysis with the reference model (FEM-PS/Contact), the approximate period of ABNT 15421 [12] provided a value $32.3 \%$ higher. In this case, for the analysis with the Equivalent Horizontal Forces Method, the use of the approximate fundamental period would lead to smaller seismic forces than those obtained with the periods extracted from the modal analysis of the models with participating masonry walls (see the design response spectrum of Figure 6).

The focus of attention is here directed to several empirical expressions that are found in the specialized literature, especially in design codes for estimating the fundamental period, based on the monitoring of buildings under earthquakes, given as a function of the total height and/or the base of the building. However, as highlighted by Asteris et al. [43], many of these expressions may or may not consider the presence of infill masonry and, therefore, provide quite variable results among them. The authors also emphasize that the height of the building and the presence of infill masonry walls are the most critical parameters that affect the fundamental period. For this reason, it is important to evaluate the fundamental period with an adequate structural model that includes masonry.

The model of plane frame without masonry, even considering the contribution of the slab and the eccentricity of the beam axis in relation to the median plane of the slab, presented a fundamental period (1.724s) close to the upper limit of ABNT 15421 [12] (1.826s) and significantly higher than the approximate value of $1.172 \mathrm{~s}$ of the same code. This overestimation of the fundamental period tends to occur in numerical models that disregard any contribution of stiffness from non-structural elements (such as infill masonry walls) in modal analysis, as previously mentioned in Amanat and Hoque [39].

\subsection{Calculation of the seismic forces: spectral method}

The procedure for calculating seismic forces using the spectral method, through applying shear building models, was implemented in the MATHCAD program. The step-by-step procedure presented in Chopra [67] was used.

The peak response of the story shear forces was obtained by combining the peak modal values according to the SRSS rule (Square Root of Square Sum).

According to ABNT NBR 15421 [12], the number of modes considered must be sufficient in order to capture $90 \%$ of the total mass. In all analyses, six vibration modes were considered, which resulted in the capture of approximately $99 \%$ of the total mass.

\subsection{Comparative analyses: spectral method}

\subsubsection{Lateral seismic loads on stories and total shear force at the base}

Table 5 contains a comparison of the values of the lateral seismic loads on each story as a function of the expression used for the equivalent width. The expression in Mainstone [54] leads to the lowest values of seismic forces between the analyzed expressions, whereas that of Decanini and Fantin [57] leads to the highest values.

Table 5. Lateral seismic loads at each story $(\mathrm{kN})$

\begin{tabular}{ccccccccc}
\hline Floor & $\begin{array}{c}\text { Without infill } \\
\text { walls }\end{array}$ & $\begin{array}{c}\text { CSA S304 } \\
{[\mathbf{6}]}\end{array}$ & $\begin{array}{c}\text { Mainstone } \\
{[\mathbf{5 4 ]}}\end{array}$ & $\begin{array}{c}\text { Durrani and } \\
\text { Luo [53] }\end{array}$ & $\begin{array}{c}\text { Liauw and } \\
\text { Kwan [56] }\end{array}$ & $\begin{array}{c}\text { Decanini and } \\
\text { Fantin [57] }\end{array}$ & $\begin{array}{c}\text { Chrysostomou and } \\
\text { Asteris [59] }\end{array}$ \\
\hline 12 & 60.23 & 79.80 & 70.84 & 73.47 & 78.59 & 85.36 & 76.05 \\
\hline 11 & 51.12 & 73.40 & 63.43 & 66.39 & 71.99 & 79.25 & 69.25 \\
\hline 10 & 42.25 & 66.25 & 55.76 & 58.93 & 64.71 & 72.19 & 61.88 \\
\hline 9 & 35.51 & 59.99 & 49.47 & 52.76 & 58.42 & 65.79 & 55.62 \\
\hline 8 & 30.26 & 54.21 & 44.00 & 47.25 & 52.68 & 59.73 & 49.97 \\
\hline 7 & 26.50 & 48.75 & 39.31 & 42.34 & 47.32 & 53.82 & 44.83 \\
\hline 6 & 23.87 & 43.45 & 35.12 & 37.81 & 42.17 & 47.89 & 39.98 \\
\hline 5 & 21.99 & 38.15 & 31.16 & 33.44 & 37.04 & 41.81 & 35.22 \\
\hline 4 & 20.15 & 32.47 & 27.02 & 28.82 & 31.55 & 35.26 & 30.15 \\
\hline 3 & 17.61 & 26.12 & 22.21 & 23.55 & 25.38 & 28.00 & 24.41 \\
\hline 2 & 13.40 & 18.66 & 16.14 & 16.70 & 18.07 & 19.64 & 17.50 \\
\hline 1 & 8.32 & 10.38 & 9.32 & 9.53 & 10.11 & 10.77 & 0 \\
\hline Base & 0 & 0 & 0 & 0 & 0 & & 9.87 \\
\hline
\end{tabular}


Table 6 contains the values of the total seismic horizontal force at the base of the structure $H_{t}$ for the different expressions used for the equivalent width. The expression in Mainstone [54] provided the lowest value (463.77 kN) and with the expression in Decanini and Fantin [57], the highest value $(599.51 \mathrm{kN})$. Thus, the maximum difference between the expressions for the total horizontal force at the base was $29.2 \%$.

Table 6. Total shear force at the base of the structure

\begin{tabular}{cc}
\hline Expression & Total shear force (kN) \\
\hline Without infill walls & 351.20 \\
\hline CSA 304 [6] & 551.61 \\
\hline Mainstone [54] & 463.77 \\
\hline Durrani and Luo [53] & 490.98 \\
\hline Liauw and Kwan [56] & 538.01 \\
\hline Decanini and Fantin [57] & 599.51 \\
\hline Paulay and Priestley [58] & 551.61 \\
\hline Chrysostomou and Asteris [59] & 514.74 \\
\hline
\end{tabular}

The Brazilian code ABNT NBR 15421 [12] specifies a minimum value for the total horizontal seismic force at the base of the structure obtained with the spectral method - called $H_{t}$. This value must not be less than $85 \%$ of the value obtained with the equivalent lateral force method - called $H$. Using the approximate fundamental period $T_{a}, H$ equal to $469.63 \mathrm{kN}$ was obtained. From Table 6 , for all models with masonry, the spectral method led to total base forces greater than $0.85 \mathrm{H}$, which is equivalent to $399.19 \mathrm{kN}$. The same did not happen for the model without masonry. In turn, when using the fundamental period extracted from modal analysis in the method of equivalent horizontal forces, the spectral method provided values very close to $0.85 \mathrm{H}$ for models with masonry.

\subsubsection{Absolute and relative lateral displacements of the stories}

Figure 8a shows the absolute lateral displacements of the stories for the model without masonry and for models with masonry according to the expression used for the equivalent diagonal. Similarly, Figure $8 \mathrm{~b}$ shows the relative lateral displacements divided by the distance between consecutive stories (interstory drifts). Absolute and relative displacements were obtained by Plane Frame model (see Figure $5 b$ ).

Figure 8a shows that, with the exception of Mainstone [54], the expressions of equivalent diagonal width provided results reasonably close to each other for absolute lateral displacements, with maximum differences around $10 \%$. On the other hand, the expression in Mainstone [54] provided values from 39.2\% to $54.3 \%$ higher than the other expressions, when considering the horizontal displacement at the top of the building.

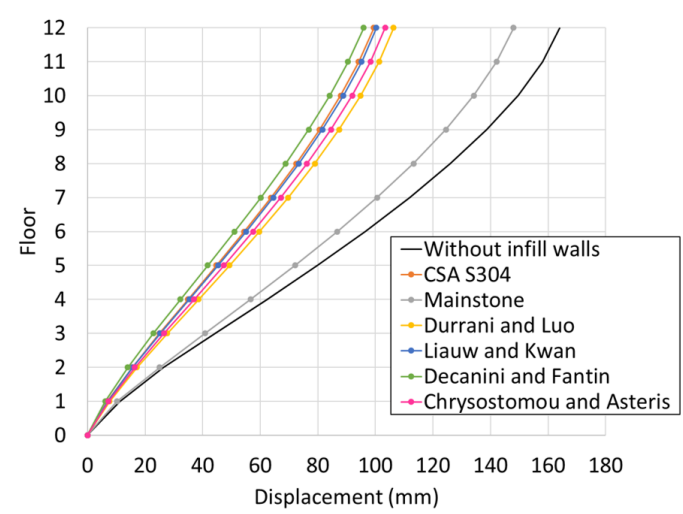

a)

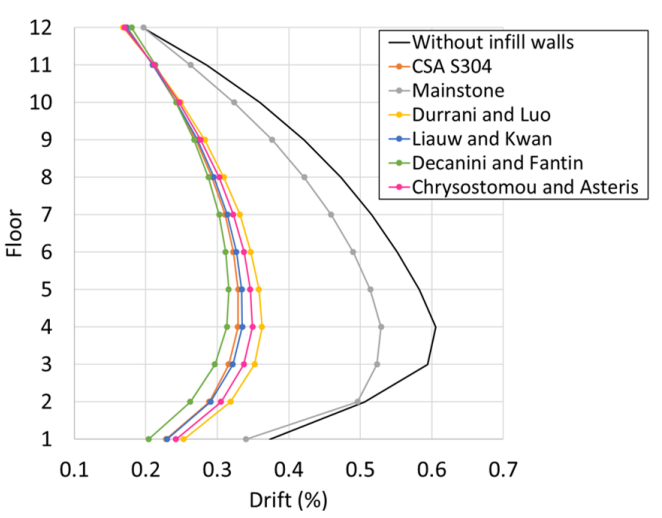

b)

Figure 8. Lateral displacement of each floor and Interstory Drifts 
Regarding interstory drifts, the maximum values occurred between stories 4 and 5 for Decanini and Fantin [57] and CSA S304 [6] expressions and between stories 3 and 4 for the other expressions. With the exception of the Mainstone expression [54], the maximum values of interstory drifts provided by the other expressions of equivalent width produced values between $0.316 \%$ and $0.363 \%$ (maximum differences around $15 \%$ ). The expression in Mainstone [54] led to a maximum interstory drift value of $0.529 \%$, i.e., it provided values $46.0 \%$ to $67.5 \%$ higher than those of other expressions. For the model without participating masonry walls, the maximum value was $0.606 \%$.

According to ABNT 15421 [12], for occupancy category I, the maximum interstory drift should be limited to $2 \%$. Therefore, in all models, including the case without participating masonry, this limit is not exceeded.

However, the referred code does not provide specific information about displacement limits for reducing damage in elements, such as infilled walls. Recent studies, such as those by Morandi et al. [23] and those by Hak et al. [68] associate drift values with the levels of damage caused to infill masonry. According to Morandi et al. [23], drifts below $0.30 \%$ cause minor damage to masonry, with superficial cracking mainly concentrated in the mortar joints. For drifts between $0.30 \%$ and $0.50 \%$, the masonry is damaged, with bi-diagonal cracking and the sliding in the mortar bed joints; however, the repairing of masonry is technically and financially viable. For $1.75 \%$ drifts, the masonry walls are severely damaged and their recovery is economically questionable, but without threat to human lives. Thus, through the values of interstory drifts in Figure 8, there is a prevision of moderate damage to the masonry due to the seismic action, but with technical and economic feasibility of repair.

\subsubsection{Second order effects $(P-\Delta)$}

For the assessment of global second-order effects, the stability coefficient $\theta$ presented in ABNT NBR 15421 [12] was used. For all models (with and without participating masonry), the stability coefficients $\theta$ were less than 0.1 . Therefore, it was unnecessary to consider the global second order effects in the structural analysis. The maximum value obtained for $\theta$ was equal to 0.0579 in models without masonry walls and equal to 0.0385 in models with masonry infill walls (Mainstone [54] expression).

\subsubsection{Internal forces in the structural members}

In order to compare results, the bending moments in columns and the compressive stress in the equivalent diagonals obtained with the different expressions from Table 1 are shown, referring only to the characteristic seismic loads. The internal forces in members were obtained through the Plane Frame model (see Figure 5b).

Figures $9 \mathrm{a}$ and $9 \mathrm{~b}$ show the maximum bending moment (absolute value) $M_{A}$ of the story, for the interior and exterior columns, respectively, along the height of the building. Noteworthy is that the $M_{A}$ bending moment is used in the approximate methods of ABNT NBR 6118 [62] for the design of members subjected to combined bending and compressive axial forces (local second-order effects).

Between the base (foundation) section and the first story, for the internal column, the bending moments were 1.34 to 1.73 times lower due to the presence of the participating masonry walls, for which the Mainstone [54] expression provided the highest values. For the exterior columns, the results were similar: values from 1.28 to 1.63 times lower than in the case without masonry, and the Mainstone [54] expression was the most conservative. By comparing all the expressions for the equivalent diagonal width, one notes that the maximum differences in columns bending moments between the base and the first story were of $27 \%$ to $30 \%$.

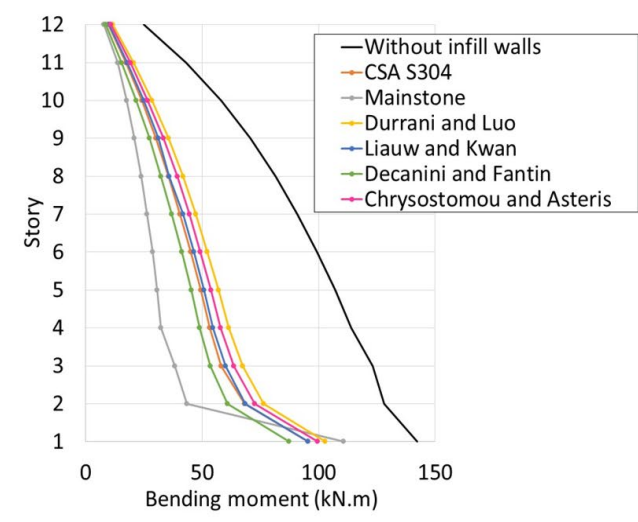

a)

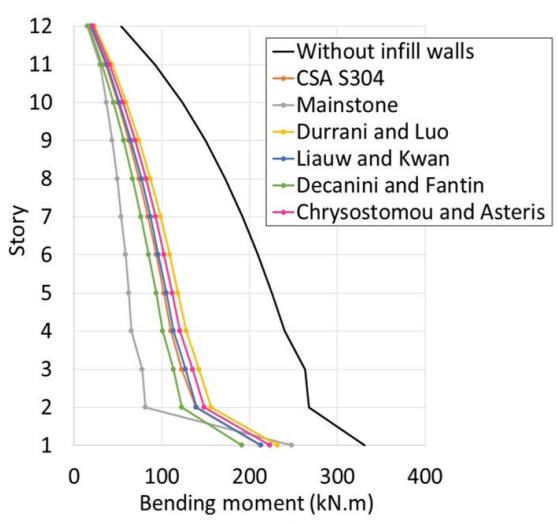

b)

Figure 9. $\mathrm{M}_{\mathrm{A}}$ bending moment of each story: a) exterior columns; b) interior column 
From the second story, analyzing both the internal and the exterior columns, Mainstone [54] is the expression that provided the lowest values of $M_{A}$ and Durrani and Luo [53], that which provided the highest values.

Between the second and fourth stories, one notes that when compared to the values obtained using the Mainstone [54] expression, the other expressions led to values of $50 \%$ to $95 \%$ higher for $M_{A}$, however, with maximum differences between these around 26\%. Along this same stretch of the building (along the height), there are signs that the presence of the participating masonry reduced the $M_{A}$ moments between 1.84 to 3.47 times for the internal column and between 1.77 to 3.23 times for the exterior columns, when compared to the case without participating masonry.

Table 7 contains the maximum values of acting compressive stress $\sigma$ in the equivalent diagonals. The stress is obtained by the ratio between the acting axial load in the diagonal-strut $N$ and the cross-sectional area, which consists of the product between the wall thickness and the diagonal equivalent width $a$. In all models from Table 7, the maximum stress value occurred between the second and third stories. The Mainstone [54] expression led to higher axial loads (maximum) in the equivalent diagonals; values 59\% to 100\% higher in relation to the other expressions. Apart from the Mainstone [54] expression, the maximum difference observed among the other expressions was $26 \%$.

Table 7. Acting compressive stresses in equivalent diagonal struts: seismic loads

\begin{tabular}{|c|c|c|c|}
\hline Expression & $\mathbf{N}(\mathbf{k N})$ & $\mathbf{a}(\mathrm{cm})$ & $\sigma(\mathrm{MPa})$ \\
\hline CSA S304 [6] & 214.46 & 151.17 & 0.747 \\
\hline Mainstone [54] & 195.37 & 76.52 & 1.344 \\
\hline Durrani and Luo [53] & 159.53 & 99.28 & 0.846 \\
\hline Liauw and Kwan [56] & 203.91 & 139.56 & 0.769 \\
\hline Decanini and Fantin [57] & 250.58 & 196.16 & 0.672 \\
\hline Paulay and Priestley [58] & 214.46 & 151.17 & 0.747 \\
\hline Chrysostomou and Asteris [59] & 184.40 & 118.06 & 0.822 \\
\hline
\end{tabular}

In Figure 10, a comparative graph is presented for the analysis of the maximum acting stress and the strength stresses, depending on the variation along the equivalent diagonal width. The strength stresses were calculated according to the code ABNT NBR 16868-1 [10], with the strength reduction factors for masonry applicable in Exceptional load combinations, in accordance with ABNT 15812 [8].

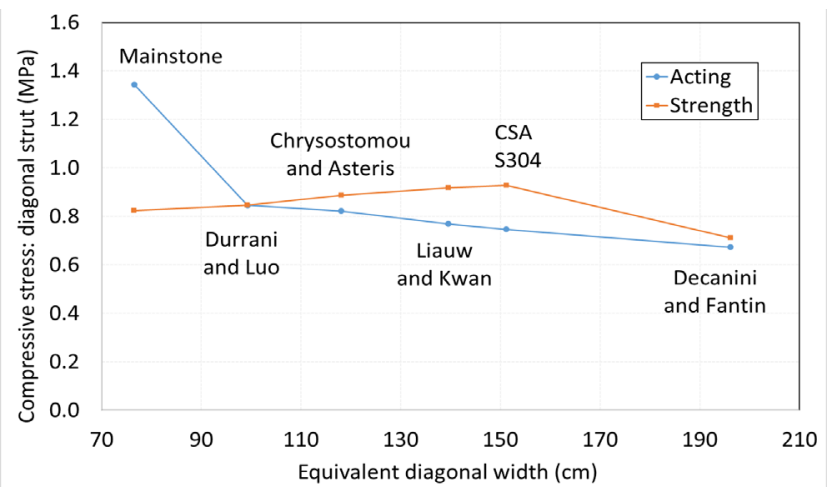

Figure 10. Compressive stresses in the diagonal strut: acting and strength values

Figure 10 shows that the increase in the equivalent diagonal width led to a decrease in internal forces in the masonry walls, although it caused an increase in the total horizontal seismic forces at the base (due to the increase in stiffness of the structure). Apart from the Mainstone [54] expression, all other expressions led to higher strength stresses than the acting stresses, demonstrating as such, a more favorable situation for the CSA S304 [6] expression, where its application resulted in a acting stress/strength stress ratio equal to 0.805 . The Mainstone [54] expression was the most conservative, with a relation between acting stress/strength stress ratio equal to 1.633 . 


\section{CONCLUSIONS}

This paper dealt with the seismic analysis of buildings with a reinforced concrete frame system and participating masonry walls. The spectral method of ABNT NBR 15421 [12] was used for determining the seismic forces. The infill walls in the structural system were simulated by the equivalent diagonal model.

Seven expressions proposed in the literature were used in the analysis performed in this paper to obtain the equivalent diagonal width. The differences provided by such expressions reached approximately $165 \%$, with the Mainstone [54] expression being the most conservative, i.e., the one that provided the lowest value for the equivalent diagonal width. This pronounced difference motivated the analysis concerning results that such expressions would lead to in terms of seismic forces in the building, internal forces in members and horizontal displacements.

Regarding the obtaining of the seismic forces, shear building models were used, in which the lateral stiffness of the stories was obtained considering the presence of the participating masonry walls, the contribution of the slabs and the eccentricity of the beam in relation to their average plane. Through modal analysis, the shear building models were compared and validated with two models: i) plane frame model with equivalent diagonals activated only for compression; ii) model with finite elements of plane stress with simulation of the problem of contact between wall and frame (reference model). The results from the modal analysis indicated the suitability of the procedure used to determine lateral stiffness in the shear building models, which provided results that were relatively close to the other two models of higher hierarchy.

As expected, the presence of the participating masonry walls promoted an increase in the lateral stiffness of the structure when compared to the case without masonry, leading to smaller fundamental vibration periods. In the numerical example analyzed in this paper, this reduction arrived at $52 \%$, depending on the structural model adopted. Among the models with participating masonry simulated with the various expressions of equivalent diagonal, the maximum difference between the fundamental periods was $26 \%$, which is, however, around $15 \%$ when compared to the reference model. Naturally, models with greater widths of equivalent diagonal had lower fundamental vibration periods. By analyzing the approximate fundamental period of ABNT NBR 15421 [12], the Brazilian code was noted as providing values up to $51 \%$ higher than the models that used equivalent diagonals (shear building and plane frames) and $32 \%$ higher in relation to the reference model. Such conclusions pertaining to the fundamental period of vibration are important especially when making decisions on the employment of the Equivalent Lateral Force Method in the determination of seismic loads.

In the seismic analysis of the numerical example, using the different expressions for the equivalent diagonal, differences of up to $29 \%$ were obtained regarding the total horizontal seismic force at the base of the structure and Mainstone [54] expression provided the lower value. However, this expression was that which provided the highest values of compression stress in the equivalent diagonals when compared to the other expressions. The Mainstone [54] expression was also the one that provided the highest values of bending moment in the columns between the foundation and the first story - a stretch where the highest bending moments were encountered in the building.

Finally, the conclusion was drawn that the differences in results observed in the structural analysis and in checks on masonry strength when applying different expressions for the equivalent diagonal width justify the need for further studies that contribute to Brazilian design codes and allow for the introduction of recommendations specific to the case of buildings with participating masonry, especially in structures resistant to seismic loads.

\section{ACKNOWLEDGMENTS}

To CNPq for financial support to the first author (Process: 308720/2018-0).

\section{REFERENCES}

[1] G. Alva, J. Kaminski Jr., G. Mohamad, and L. Silva, "Serviceability limit state related to excessive lateral deformations to account for infill walls in the structural model," Ibracon Struct. Mater. J., vol. 8, no. 3, pp. 390-426, 2015, http://dx.doi.org/10.1590/S198341952015000300008.

[2] L. Silva, "Modelagem de pórticos de concreto armado preenchidos com a consideração de aberturas nos painéis de alvenaria," M.S. thesis, Univ. Fed. Santa Maria, Santa Maria, 2014. [Online]. Available: https://www.ufsm.br/cursos/pos-graduacao/santamaria/ppgec/

[3] G. Alva and G. Montandon, "Modelos estruturais para a análise de pórticos preenchidos com alvenaria em edifícios de concreto armado," Ibracon Struct. Mater. J., vol. 12, no. 5, pp. 1058-1085, 2019, http://dx.doi.org/10.1590/s1983-41952019000500006.

[4] Applied Technology Council, Evaluation of Earthquake Damaged Concrete and Masonry Wall Buildings, FEMA $306,1998$.

[5] Masonry Standards Joint Committee, Building Code Requirements for Masonry Structures, TMS 402-16, 2016. 
[6] Canadian Standards Association, Design of Masonry Structures, S304-14, 2014.

[7] New Zealand Standard, Design of Reinforced Concrete Masonry Structures, NZS 4230, 2004.

[8] Associação Brasileira de Normas Técnicas, Alvenaria Estrutural - Blocos Cerâmicos - Parte 1: Projetos, NBR $15812,2010$.

[9] Associação Brasileira de Normas Técnicas, Alvenaria Estrutural - Blocos de Concreto - Parte 1: Projetos, NBR $15961,2011$.

[10] Associação Brasileira de Normas Técnicas, Alvenaria Estrutural - Parte 1: Projeto, NBR 16868, 2020.

[11] R. Rodrigues, C. Mazzilli, and T. Bittencourt, "Comparative analysis of normative provisions for seismic design and detailing of reinforced concrete structures," Ibracon Struct. Mater. J., vol. 12, no. 5, pp. 1220-1247, 2019, http://dx.doi.org/10.1590/s198341952019000500013.

[12] Associação Brasileira de Normas Técnicas, Projeto de Estruturas Resistentes a Sismos - Procedimento, NBR 15421, 2006.

[13] P. Nóbrega, B. Souza, M. Felipe, and S. Nóbrega, "Sobre os mapas de perigo sísmico para o projeto de estruturas," in $A n$. $61^{\circ}$ Cong. Bras. Concr., 2019, pp. 1-16.

[14] A. Mehrabi, P. Shing, M. Schuller, and J. Noland, "Experimental evaluation of Masonry-Infilled RC frames," J. Struct. Eng., vol. 122, no. 3, pp. 228-237, 1996, http://dx.doi.org/10.1061/(ASCE)0733-9445(1996)122:3(228).

[15] A. Durrani and S. Haider, "Seismic response of R/C frames with unreinforced masonry infills," in Proc. 11th World Conf. Earthquake Eng., Acapulco, 1996, pp. 1-8.

[16] R. Flanagan and R. Bennett, "In-plane behavior of structural clay tile infilled frames," J. Struct. Eng., vol. 125, no. 6, pp. 590-599, 1999, http://dx.doi.org/10.1061/(ASCE)0733-9445(1999)125:6(590).

[17] G. Al-Chaar, M. Issa, and S. Sweeney, "Behavior of masonry-infilled nonductile reinforced concrete frames," J. Struct. Eng., vol. 128, no. 8, pp. 1055-1063, 2002, http://dx.doi.org/10.1061/(ASCE)0733-9445(2002)128:8(1055).

[18] P. Asteris, D. Kakaletsi, C. Chrysostomou, and E. Smyrou, "Failure modes of in-filled frames," Electron. J. Struct. Eng., vol. 11, no. 1, pp. 11-20, 2011.

[19] A. Tasnimi and A. Mohebkhah, "Investigation on the behavior of brick-infilled steel frames with openings, experimental and analytical approaches," Eng. Struct., vol. 33, no. 3, pp. 968-980, 2011, http://dx.doi.org/10.1016/j.engstruct.2010.12.018.

[20] H. Liu and P. Manesh, "Concrete masonry infilled steel frames subjected to combined in-plane lateral and axial loading - an experimental study," Eng. Struct., vol. 52, pp. 331-339, 2013, http://dx.doi.org/10.1016/j.engstruct.2013.02.038.

[21] A. Mansouri, M. Marefat, and M. Khanmohammadi, "Experimental evaluation of seismic performance of low-shear strength masonry infills with openings in reinforced concrete frames with deficient seismic details," Struct. Des. Tall Spec. Build., vol. 23, no. 15, pp. 1190-1210, 2014, http://dx.doi.org/10.1002/tal.1115.

[22] S. Basha and H. Kaushik, "Behavior and failure mechanisms of masonry-infilled RC frames (in low-rise buildings) subject to lateral loading," Eng. Struct., vol. 111, pp. 233-245, 2016, http://dx.doi.org/10.1016/j.engstruct.2015.12.034.

[23] P. Morandi, S. Hak, and G. Magenes, "Performance-based interpretation of in-plane cyclic tests on RC frames with strong masonry infills," Eng. Struct., vol. 156, pp. 503-521, 2018, http://dx.doi.org/10.1016/j.engstruct.2017.11.058.

[24] I. Doudoumis, "Finite element modelling and investigation of the behaviour of elastic infilled frame under monotonic loading," Eng. Struct., vol. 29, no. 6, pp. 1004-1024, 2007, http://dx.doi.org/10.1016/j.engstruct.2006.07.011.

[25] G. Mondal and S. Jain, "Lateral stiffness of masonry infilled reinforced concrete (RC) frames with central opening," Earthq. Spectra, vol. 24, no. 3, pp. 701-723, 2008, http://dx.doi.org/10.1193/1.2942376.

[26] P. Asteris, "Lateral stiffness of brick masonry infilled plane frames," J. Struct. Eng., vol. 129, no. 8, pp. 1071-1079, 2003, http://dx.doi.org/10.1061/(ASCE)0733-9445(2003)129:8(1071).

[27] A. Gosh and A. Amde, "Finite element analysis of infilled frames," J. Struct. Eng., vol. 128, no. 7, pp. 881-889, 2002, http://dx.doi.org/10.1061/(ASCE)0733-9445(2002)128:7(881).

[28] A. Mohyeddin, H. Goldsworthy, and E. Gad, "FE modelling of RC frames with masonry infill panels under in-plane and out-of-plane loading," Eng. Struct., vol. 51, pp. 73-87, 2013, http://dx.doi.org/10.1016/j.engstruct.2013.01.012.

[29] A. Stavridis and P. Shing, "Finite-element modeling of nonlinear behavior of masonry-infilled RC frames," J. Struct. Eng., vol. 136, no. 3, pp. 285-296, 2010, http://dx.doi.org/10.1061/(ASCE)ST.1943-541X.116.

[30] G. Baloevic, J. Radnic, and A. Harapin, "Numerical dynamic tests of masonry-infilled RC frames," Eng. Struct., vol. 50, pp. 43-55, 2013, http://dx.doi.org/10.1016/j.engstruct.2012.11.034.

[31] M. Mohammadi and S. M. Motovali Emami, "Multi-bay and pinned connection steel infilled frames; an experimental and numerical study," Eng. Struct., vol. 188, pp. 43-59, 2019, http://dx.doi.org/10.1016/j.engstruct.2019.03.028.

[32] F. Crisafulli, A. Carr, and R. Park, "Analytical modelling of infilled frame structures - a general review," Bull. N. Z. Soc. Earthq. Eng., vol. 33, no. 1, pp. 30-47, 2000.

[33] W. El-Dakhakhni, M. Elgaaly, and A. Hamid, "Three-strut model for concrete mansory-infilled steel frames," J. Struct. Eng., vol. 129, no. 2, pp. 177-185, 2003, http://dx.doi.org/10.1061/(ASCE)0733-9445(2003)129:2(177). 
[34] P. Asteris, S. Antoniou, D. Sophianopoulos, and C. Chrysostomou, "Mathematical macromodeling of infilled frames: state of the art," J. Struct. Eng., vol. 137, no. 12, pp. 1508-1517, 2011, http://dx.doi.org/10.1061/(ASCE)ST.1943-541X.0000384.

[35] A. Fiore, A. Netti, and P. Monaco, "The influence of masonry infill on the seismic behaviour of RC frame buildings," Eng. Struct., vol. 44, pp. 133-145, 2012, http://dx.doi.org/10.1016/j.engstruct.2012.05.023.

[36] G. Uva, D. Raffaele, F. Porco, and A. Fiore, "On the role of equivalent strut models in the seismic assessment of infilled RC buildings," Eng. Struct., vol. 42, pp. 83-94, 2012, http://dx.doi.org/10.1016/j.engstruct.2012.04.005.

[37] S. Sattar and A. Liel, "Seismic performance of non-ductile reinforced concrete frames with masonry infill walls -I: development of a finite element enhanced strut modeling approach," Earthq. Spectra, vol. 32, no. 2, pp. 795-818, 2016, http://dx.doi.org/10.1193/90914eqs139m.

[38] P. Asteris, C. Repapis, F. Foskolos, A. Fotos, and A. Tsaris, "Fundamental period of infilled RC frame structures with vertical irregularity," Struct. Eng. Mech., vol. 61, no. 5, pp. 663-674, 2017, http://dx.doi.org/10.12989/sem.2017.61.5.663.

[39] K. Amanat and E. Hoque, "A rationale for determining the natural period of RC building frames having infill," Eng. Struct., vol. 28, no. 4, pp. 495-502, 2006, http://dx.doi.org/10.1016/j.engstruct.2005.09.004.

[40] M. Kose, "Parameters affecting the fundamental period of RC building with infill walls," Eng. Struct., vol. 31, no. 1, pp. 93-102, 2009, http://dx.doi.org/10.1016/j.engstruct.2008.07.017.

[41] P. Ricci, G. Verderame, and G. Manfredi, "Analytical investigation of elastic period of infilled RC MRF buildings," Eng. Struct., vol. 33, no. 2, pp. 308-319, 2011, http://dx.doi.org/10.1016/j.engstruct.2010.10.009.

[42] D. Perrone, M. Leone, and M. Aiello, "Evaluation of the infill influence on the elastic period of existing frames," Eng. Struct., vol. 123, pp. 419-433, 2016, http://dx.doi.org/10.1016/j.engstruct.2016.05.050.

[43] P. Asteris, C. Repapis, E. Repapi, and L. Cavaleri, "Fundamental period of infilled reinforced concrete frame structures," Struct. Infrastruct. Eng., vol. 13, no. 7, pp. 929-941, 2016, http://dx.doi.org/10.1080/15732479.2016.1227341.

[44] R. Alvarenga, “Análise teórico-experimental de estruturas compostas de pórticos de aço preenchidos com alvenaria de concreto celular autoclavado,” Ph.D. dissertation, Univ. São Paulo, São Carlos, 2002. [Online]. Available: http://www.set.eesc.usp.br/producao/

[45] E. Santos, "Influência da alvenaria no comportamento estrutural de edifícios altos de concreto armado," M.S. thesis, Univ. Cat. Pernambuco, Recife, 2007.

[46] E. Tanaka, "Influência da alvenaria dotada de aberturas na rigidez global de um edifício,” M.S. thesis, Univ. Est. Campinas, Campinas, 2011.

[47] F. Madia, "Estudo de pórticos preenchidos com alvenaria,” M.S. thesis, Univ. Fed. São Carlos, São Carlos, 2012.

[48] P. Sousa, "Efeito dos painéis de vedação nas características dinâmicas de edificações de concreto armado,” M.S. thesis, Univ. Fed. Rio de Janeiro, 2014.

[49] M. Pitanga, "Contribuição ao estudo de pórticos de concreto armado preenchidos com alvenaria de blocos cerâmicos,” Ph.D. dissertation, Univ. Fed. Pernambuco, Recife, 2016.

[50] G. Montandon, "Modelos estruturais para a análise de pórticos preenchidos com blocos cerâmicos em edifícios de concreto armado," M.S. thesis, Univ. Fed. Uberlândia, Uberlândia, 2018. [Online]. Available: http://www.ppgec.feciv.ufu.br/

[51] W. Medeiros, "Pórticos em concreto pré-moldado preenchidos com alvenaria participante,” M.S. thesis, Univ. Fed. São Carlos, São Carlos, 2018.

[52] A. Grandi, “Avaliação experimental por meio de ensaios cíclicos de pórtico de aço preenchido com alvenaria participante,” M.S. thesis, Univ. Fed. Viçosa, Viçosa, 2018.

[53] A. Durrani and Y. Luo, "Seismic retrofit of flat-slab buildings with masonry infills," in Proc. NCEER Workshop on Seismic Response Mas. Infills, Buffalo, N.Y., 1994, pp. 1-8.

[54] R. Mainstone, Supplementary Note on the Stiffness and Strengths of Infilled Frames. Garston: Building Research Station, 1974.

[55] A. Hendry, Structural Brickwork. London: MacMillan, 1981. http://dx.doi.org/10.1007/978-1-349-81439-8.

[56] T. Liauw and K. Kwan, "Nonlinear behavior of non-integral infilled frames," Comp. and Struct., vol. 18, no. 3, pp. 551-560, 1984, http://dx.doi.org/10.1016/0045-7949(84)90070-1.

[57] L. Decanini and G. Fantin, "Modelos simplificados de la mampostería incluida en porticos: caracteristicas de rigidez y resistencia lateral en estado limite," in J. Argentinas Ing. Estructural, vol. 2, Buenos Aires, Argentina, 1986, pp. 817-836.

[58] T. Paulay and M. Priestley, Seismic Design of Reinforced Concrete and Masonry Buildings. New York: Wiley, 1992. http://dx.doi.org/10.1002/9780470172841.

[59] C. Chrysostomou and P. Asteris, "On the in-plane properties and capacities of infilled frames," Eng. Struct., vol. 41, pp. 385-402, 2012, http://dx.doi.org/10.1016/j.engstruct.2012.03.057.

[60] P. Asteris, D. Cotsovos, C. Chrysostomou, A. Mohebkhah, and G. Al-Chaar, "Mathematical micromodeling of infilled frames: state of the art," Eng. Struct., vol. 56, pp. 1905-1921, 2013, http://dx.doi.org/10.1016/j.engstruct.2013.08.010. 
[61] G. Alva, J. Kaminski Jr., A. Rigão, and M. Pinheiro, "Consideração das alvenarias participantes na rigidez lateral de edifícios de concreto armado," in An. 61 Congr. Bras. Concr., Fortaleza, 2019, pp. 1-16.

[62] Associação Brasileira de Normas Técnicas, Projeto de Estruturas de Concreto - Procedimento, NBR 6118, 2014.

[63] N. Caterino, E. Cosenza, and B. Azmoodeh, "Approximate methods to evaluate storey stiffness and interstory drift of RC buildings in seismic areas," Struct. Eng. Mech., vol. 46, no. 2, pp. 245-267, 2013, http://dx.doi.org/10.12989/sem.2013.46.2.245.

[64] M. Gaetani d'Aragona, M. Polese, E. Cosenza, and A. Prota, "Simplified assessment of maximum interstory drift for RC buildings with irregular infills distribution along the height," Bull. Earthquake Eng., vol. 17, no. 2, pp. 707-736, 2019, http://dx.doi.org/10.1007/s10518-018-0473-y.

[65] M. Saatcioglu and J. Humar, "Dynamic analysis of buildings for earthquake-resistant design," Can. J. Civ. Eng., vol. 30, no. 2, pp. 338-359, 2003, http://dx.doi.org/10.1139/102-108.

[66] J. Araújo, "Avaliação dos métodos simplificados para o cálculo de lajes maciças apoiadas em vigas flexíveis," Teor. Prat. Eng. Civ., no. 12, pp. 1-11, 2008.

[67] A. Chopra, Dynamic of Structures: Theory and Applications to Earthquake Engineeering, 4th ed. Upper Saddle River: Prentice Hall, 2012.

[68] S. Hak, P. Morandi, G. Magenes, and T. Sullivan, "Damage control for clay masonry infills in the design of RC frame structures," $J$. Earthquake Eng., vol. 16, no. S1, pp. 1-35, 2012, http://dx.doi.org/10.1080/13632469.2012.670575.

Author contributions: GMSA: conceptualization, data curation, formal analysis, investigation, methodology, validation, writing. AOR: investigation, methodology, writing. JKJ and MASP: supervision.

Editors: Sérgio Hampshire de Carvalho Santos, Guilherme Aris Parsekian. 